\title{
Susceptibility of invertebrate larvae to predators: how common are post-capture larval defenses?
}

\author{
Stephan G. Bullard ${ }^{1, *}$, Niels L. Lindquist ${ }^{1}$, Mark E. Hay ${ }^{2}$ \\ ${ }^{1}$ University of North Carolina, Institute of Marine Sciences, 3431 Arendell St., Morehead City, North Carolina 28557, USA \\ ${ }^{2}$ School of Biology, Georgia Institute of Technology, Atlanta, Georgia 30332-0230, USA
}

\begin{abstract}
Predation is believed to be a major source of mortality for larvae of benthic invertebrates, but the palatability of larvae commonly found in the water column has rarely been assessed. Larval palatability assays were conducted by collecting live invertebrate larvae from a temperate field site and offering them to a suite of common predators (the fishes Lagodon rhomboides, Leiostomus xanthurus, and Monacanthus hispidus and the hard coral Oculina arbuscula). By crushing larvae that were rejected intact and re-offering them to predators, it was possible to distinguish between defenses based on morphological and chemical characteristics of the larvae. Additionally, abundance data were collected for taxonomic groups of larvae at our sampling location. The majority of invertebrate larvae were palatable to consumers. Most predators readily consumed polychaete larvae, barnacle nauplii, bivalve veligers, shrimp zoeae, crab megalopae, phoronid actinotrochs, and hemichordate tornaria (which together accounted for $65 \%$ of meroplankton abundance), suggesting that these larvae lacked effective morphological or chemical defenses. Against at least 1 fish predator, a significant number of gastropod veligers, barnacle cyprids, crab zoeae, and stomatopod larvae (which accounted for $34 \%$ of meroplankton abundance) appeared to be morphologically defended. Larvae from these groups tended to be rejected whole, but were consumed by fishes once they were crushed. A significant number of nemertean pilidia, asteroid bipinnaria, and cnidarian planulae (which accounted for only $0.2 \%$ of meroplankton abundance) were rejected both whole and crushed, suggesting that some species or individuals within these taxa may be chemically defended. Thus, the majority of larvae from this assemblage of temperate meroplankton lacked physical or chemical defenses against potential predators ( 3 fishes and 1 cnidarian). Among the remaining larvae, physical resistance to predators was much more common than chemical resistance.
\end{abstract}

KEY WORDS: Invertebrate larvae Chemical ecology · Morphological defense Predator-prey

\section{INTRODUCTION}

An important concept in larval ecology is the idea that most invertebrate larvae are readily consumed when they are captured by planktivores (Thorson 1946, Young \& Chia 1987, Morgan 1995). A large body of observational evidence supports the contention that larvae are palatable to consumers: (1) gut content analyses of potential larval predators demonstrate that many species of larvae are consumed by predators (Reeve \& Walter 1978, Feigenbaum \& Maris 1984, Sebens \& Koehl 1984, Young \& Chia 1987, Bingham \& Walters 1989, Gerking 1994, Baier \& Purcell 1997); (2) negative correlations exist between planktivore

•E-mail: sbullard@email.unc.edu abundances and larval abundances in the field (Thayer et al. 1974, Burrell \& Van Engel 1976); (3) declines have been observed in the abundance of planktonic larval cohorts over time (Glynn 1973, Rumrill 1990 and references therein); and (4) direct field observations have been made of the consumption of ascidian larvae that were followed from the time of their release (Olson \& McPherson 1987, Davis \& Butler 1989, Stoner $1990)$. Despite the intense predation pressure that invertebrate larvae may face, field studies have demonstrated that predators are selective in their consumption of larvae (Hobson \& Chess 1976, Sebens \& Koehl 1984, Purcell \& Nemazie 1992). Additionally, laboratory investigations have shown that many invertebrate larvae possess behavioral (Forward 1977, Morgan 1987), morphological (Pennington \& Chia 1984 Morgan 1989, Morgan \& Christy 1996), and/or chemi- 
cal (Lucas et al. 1979, Young \& Bingham 1987, McClintock \& Vernon 1990, Lindquist et al. 1992, Lindquist 1996, Lindquist \& Hay 1996) traits that reduce their susceptibility to predators. Therefore, larvae of different invertebrates may differ dramatically in their vulnerabilities to predators.

To determine how commonly defended larvae occur in a natural assemblage of planktonic larvae, we offered taxonomically diverse, field-captured larvae to 4 common predators: juvenile stages of 3 fishes, filefish Monacanthus hispidus, spot Leiostomus xanthurus, and pinfish Lagodon rhomboides, and a temperate coral, Oculina arbuscula. Spot and pinfish are among the most abundant fishes in the lower estuaries of North Carolina during spring and early summer (Weinstein 1979, Hettler et al. 1997), and both are voracious plankton feeders (Kjeslon et al. 1975). Filefish can be important estuarine predators and are also abundant in the pelagic Sargassum community, where they reach densities of 75 ind. $\mathrm{I}^{-1}$ of Sargassum plant (Stachowicz \& Lindquist 1996). Although adult filefish are mainly substrata feeders, juveniles consume a variety of planktonic prey items including invertebrate larvae (Clements \& Livingston 1983, S. G. Bullard pers. obs.). O. arbuscula is a common member of the benthic hard-bottom community in North Carolina and can reach densities of 30 adult colonies and 4000 juvenile recruits $\mathrm{m}^{-2}$ (Miller \& Hay 1996).

\section{METHODS}

Collection sites and organisms. Larval predators were collected from sites near Morehead City, North Carolina, USA. Juvenile spot (12 to $18 \mathrm{~mm}$ standard length) were collected with dipnets at the Dockside Marina, Morehead City. Juvenile pinfish (17 to $33 \mathrm{~mm}$ standard length) were seined from seagrass beds near Harkers Island, North Carolina. Juvenile filefish (17 to $28 \mathrm{~mm}$ standard length) were captured $32 \mathrm{~km}$ offshore from Morehead City, by passing dipnets under floating mats of Sargassum spp. Corals were collected from the deck of the 'Theodore Parker', a 134 m long sunken ship $3.5 \mathrm{~km}$ offshore from Atlantic Beach, North Carolina (10 $\mathrm{m}$ depth). Feeding assays were conducted from September to October 1996 for filefish, from March to April 1997 for spot, and in June 1997 for corals and pinfish.

Live invertebrate larvae used in palatability assays were captured in plankton tows taken from floating docks at the Dockside Marina. This location was chosen because of its large expanse of dock space $\left(762 \mathrm{~m}^{2}\right.$ total area), and because the extensive fouling community on the underside of the docks was likely to enhance the diversity of benthic invertebrate larvae captured. Additionally, the site was being used in a plankton abundance monitoring project, allowing the types of larvae captured during this study to be evaluated within a larger temporal context.

Plankton tows were taken with a $202 \mu \mathrm{m}$ plankton net that had a $0.5 \mathrm{~m}^{2}$ rectangular aperture. All tows were $10 \mathrm{~min}$ passive surface tows taken $1.5 \mathrm{~h}$ before low or high tide. At these times, tidal flow averaged about $22.5 \mathrm{~cm} \mathrm{~s}^{-1}$. Thus, approximately $67500 \mathrm{l}$ of water were sampled in each tow. Once a plankton sample was obtained, the live plankton were rinsed with filtered seawater out of the cod end of the net and into a bucket. Then $5 \mu \mathrm{m}$ filtered seawater was added to the sample until its total volume was $10 \mathrm{l}$. The sample was then transferred to the lab and gently aerated with aquarium bubblers. Palatability assays were always completed within $4.5 \mathrm{~h}$ of plankton capture. Most of the plankton were still alive after $6 \mathrm{~h}$, and some after $24 \mathrm{~h}$.

Previous studies suggested that some sessile, softbodied invertebrates in tropical habitats release conspicuous, distasteful, short-lived larvae during daylight hours (Young \& Bingham 1987, Lindquist et al. 1992, Lindquist \& Hay 1996, Lindquist et al. 1997). If related temperate invertebrates release short-lived, distasteful larvae during the day, we would expect to find significantly more larvae to be rejected in the day samples than in the night samples for these taxa. However, because contrasting the palatability of day-versus night-captured larvae was very labor intensive, we ran day-night contrasts only for filefish. For these assays, plankton samples were not taken around sunrise and sunset ( $1 \mathrm{~h}$ before and after sunrise/sunset) so that larvae that exhibited diel migrations would be present in only the day, or only the night samples, but not in both.

Larval susceptibility to predators. Predators used in feeding assays were maintained individually in $500 \mathrm{ml}$ plastic bowls filled with $400 \mathrm{ml}$ of $5 \mu \mathrm{m}$ filtered seawater. Bowls were cleaned daily and kept in a flowthrough seawater table to maintain a constant temperature. Predators were fed a mixed diet of frozen brine shrimp and 'squid-paste' (homogenized squid mantle tissue mixed with an equal volume of distilied water and gelled with sodium alginate at $2 \%$ of the total wet weight, Lindquist \& Hay 1995). Predators were fed twice daily, once in the morning (at about 10:00 h) and once in the evening (at about 18:00 h). During days on which palatability assays were performed, the second feeding took place 1 to $1.5 \mathrm{~h}$ before the initiation of the palatability assay instead of in the evening. This feeding regime assured that the predators were well fed before the assay began so that they would not consume less palatable items simply because of excessive hunger. For filefish assays, on days when night-time palatability assays were conducted, fish received a 
total of 3 feedings at 10:00,18:00, and $1 \mathrm{~h}$ before the night assay.

Because most larvae were small and difficult to see, each predator's bowl was cleaned before an assay. This mace it easier for the observer, and perhaps the fish, to see the larvae. The cleaning followed the predators' second feeding and generally took $1 \mathrm{~h}$. Palatability assays began as soon as all bowls were clean. $600 \mathrm{ml} \mathrm{sub-samples} \mathrm{were} \mathrm{taken} \mathrm{from} \mathrm{the} \mathrm{well-}$ mixed live plankton sample, placed into a 1 l glass dish, and examined on bright-field and dark-field backgrounds with a $2.5 \times$ magnification visor. Larvae were placed individually within a small drop of water on a clean polystyrene surface. Once 8 to 10 larvae were captured, each larva was identified to group (e.g. polychaete larvae, barnacle nauplii, crab zoeae, etc.) under $25 \times$ magnification and presented individually to the predators. Because we were interested in determining the commonality of larval defense in our temperate system, efforts were made to ensure that a diversity of larval forms were offered. Unique or rare larval forms were always selected, and as many different 'types' and sizes as possible of the more common larval forms (such as polychaete larvae and crab zoeae) were selected.

To present items (larvae or palatable brine shrimp controls) to fish, the tip of the pipette was placed approximately $2 \mathrm{~cm}$ in front of the fish and the item was squirted towards the fish. Fish generally attacked larvae or brine shrimp within 0.5 to $2 \mathrm{~s}$. If a fish did not attack the item within $5 \mathrm{~s}$, the item was sucked back into the pipette, and the process was repeated until the fish attacked the item, the fish lost interest in the pipette, or the item was 'lost' in the dish. Fishes were offered control foods and larvae in sequence. Corals had a brine shrimp placed onto 1 open polyp as a palatable control while a larva was placed simultaneously onto an adjacent open polyp.

Once a larva had been selected and identified, a piece of brine shrimp of approximately the same size as the larva was presented to a predator. This piece of brine shrimp served as a feeding control. If the brine shrimp was consumed, the predator was assumed to be willing to feed and the assay proceeded. If the brine shrimp was rejected (taken into the mouth but then spit out), or if the predator was unwilling to sample the control, the predator was assumed to be satiated and was not used in that palatability assay.

After a fish had accepted the brine shrimp, it was offered an invertebrate larva. Fish might not sample a larva because the fish had stopped feeding, the fish could not see the larva, or the fish was unwilling to sample the larva. As we were interested in examining the palatability of larvae (i.e. the predators willingness to consume a larva once it had been attacked), such fish did not provide any useful data during that particular assay. Fish rarely ignored larvae, which were sampled in about $95 \%$ of our replicates. If the larva was sampled and consumed, the larva was recorded as palatable, and the assay with that particular fish was completed. If the larva was sampled and rejected (spit out), the rejected larva was recovered from the bowl, and the assay progressed to the next level.

There were 3 reasons why a larva might be rejected: (1) the predator became satiated after consuming the first piece of brine shrimp; (2) the larva possessed a morphological defense, or a combination of morphological and behavioral defenses such as spine flaring (Pennington \& Chia 1984, Morgan 1987) that made the fish unwilling or unable to consume it; (3) the larva possessed a chemical defense that rendered it unpalatable. In an effort to differentiate between these possibilities, additional steps were included in the assays. To test if the predator had become satiated, a second brine shrimp control was offered. This second control was never rejected, indicating that satiation never occurred during our assays.

Given that predators did not become satiated during assays, rejected larvae may have had a chemical or a morphological defense. To nullify most morphological resistance, rejected larvae were crushed thoroughly with a pair of forceps. By the end of this procedure, each larva was reduced to an amorphous mass of tissue. The crushed larva was then re-presented to the predator that had initially rejected it. Acceptance of this crushed larva suggested that initial rejection was due to a morphological rather than a chemical trait.

Continued rejection of the crushed larva suggested that it was chemically defended or that the predator was satiated. Thus, a third brine shrimp control was offered to the predator to assess the possibility of satiation. This third control was rejected only once during feeding assays, and the results of that replicate were discarded.

For palatability assays, careful records were maintained to ensure that each individual predator received only 1 of each larval type, thus assuring independence among replicates. For example, once a particular predator had been offered 1 polychaete larva, that individual predator was not presented with a polychaete larva again. Differences between consumption of controls and larvae were evaluated using Fisher's Exact tests.

Temporal abundance of meroplankton. Changes in the abundance of meroplankton groups were monitored at the Dockside Marina from December 1995 to December 1996. Samples were collected at weekly intervals using a sampling regime that was fixed to tidal and lunar periodicity. Three replicate samples were collected $1.5 \mathrm{~h}$ before each slack tide during a 
$24 \mathrm{~h}$ period on the full, new, and quarter moons. Thus, a total of 12 samples were taken during 4 separate sampling periods ( 1 before each slack low and 1 before each slack high) within a $24 \mathrm{~h}$ period each week. Each sample consisted of a 5 min passive surface tow using the $202 \mu \mathrm{m}$ plankton. net described above. Current speed was recorded using a General Oceanics flowmeter (model 2030) that was held in place at the opening of the plankton net.

Once collected, samples were processed so that abundance calculations could be performed for each meroplankton group. The contents of the plankton net's cod end were rinsed into a bucket, and $5 \mu \mathrm{m}$ filtered seawater was added to the sample until the total sample volume was $5 \mathrm{l}$. The $5 \mathrm{l}$ sample was then well mixed and a $500 \mathrm{mI}$ sub-sample was withdrawn. This sub-sample was concentrated on a $102 \mu \mathrm{m}$ sieve, rinsed into a $250 \mathrm{ml}$ Nalgene bottle, and preserved in $250 \mathrm{ml}$ of a $5 \%$ buffered Formalin-seawater solution. During abundance enumeration, sub-samples were obtained from the preserved samples by mixing the $250 \mathrm{ml}$ sample and withdrawing a specific amount of the sample with a graduated syringe. The abundance of the more common meroplankton groups (polychaete larvae, barnacle nauplii, barnacle cyprids, and gastropod veligers) was determined by counting all individuals present in 3 replicate $5 \mathrm{ml}$ sub-samples. The abundance of all other meroplankton groups was determined by counting all individuals present in a $100 \mathrm{ml}$ sub-sample. Once raw plankton counts had been obtained for each sample, plankton numbers were converted to densities (no. $\mathrm{m}^{-3}$ ) using the data from the flow meter.

Identification of larval forms. Although we would have liked to determine the palatability of individual species of larvae, it was not possible to identify live, field-captured larvae to the species level. Instead we assessed the palatability of taxonomic groups. To better quantify the diversity of larval forms that were offered to filefish, a quasi-taxonomic examination was made of planktonic material collected during the time period when filefish palatability assays were performed (i.e. September to October 1996). During the processing of these samples, efforts were made to isolate and identify each of the different types of larvae that were present during sampling. For several taxonomic groups it was possible to identify larvae to species and/or stage, and for all major taxa it was possible to sort larvae into separate types. While we are not certain whether these types represented unique species, each type was morphologically distinct and easily distinguishable from other types. A representative of each larval type was photographed with a video camera and/or sketched to form an archival reference (available by contacting S. G. Bullard).

\section{RESULTS}

\section{Palatability of larvae}

Of the 1221 larvae offered to predators, $85.2 \%$ were consumed (Table 1). Larval consumption frequencies for predators ranged from $72.9 \%$ for spot to $90.5 \%$ for filefish. This variation in feeding among the different predators could be due to different preferences for different larval groups, or to seasonal differences in the types of larvae captured during each assay period.

Of the larval groups offered to filefish, gastropod veligers and barnacle cyprids were consumed at significantly lower levels than brine shrimp controls $(80$ and $82 \%$ consumed, respectively, compared to $100 \%$ consumption of brine shrimp) (Fig. 1A). Additionally, stomatopod larvae, which were captured most frequently at night, were also consumed significantly less often than the control food $(30 \%$ consumed compared to $100 \%$ consumption of brine shrimp) (Fig. 1B). All of the rejected gastropod veligers, barnacle cyprids and stomatopod larvae were eaten once they were crushed, suggesting a morphological rather than chemical defense. Consumption of pilidia (larval nemerteans) nearly differed significantly from consumption of controls ( $\mathrm{p}=0.06$, Fisher's Exact test), with unpalatable individuals being rejected both whole and crushed. Larvae in all other taxonomic groups were consumed by filefish at rates that were not significantly different from brine shrimp controls. There were no significant differences in the palatability of day versus night captured larvae (Fig. 1A,B). However, it should be noted that in several cases larvae of particular taxonomic groups (such as stomatopod larvae) were underrepresented in either the day-time or the night-time collections, precluding rigorous comparisons between times for these taxonomic groups.

Spot consumed significantly fewer gastropod veligers, pilidia, barnacle cyprids, crab zoeae, and asteroid bipinnaria than brine shrimp controls (consuming 57 ,

Table 1 Consumption of larval forms by different predators. Consumed whole indicates palatable larvae, consumed crushed indicates possible morphological defense, and rejected whole and crushed indicates possible chemical defense

\begin{tabular}{|lcccc|}
\hline Predator & $n$ & \multicolumn{3}{c}{ \% of larvae } \\
\cline { 3 - 5 } & & $\begin{array}{c}\text { Consumed } \\
\text { whole }\end{array}$ & $\begin{array}{c}\text { Consumed } \\
\text { crushed }\end{array}$ & $\begin{array}{c}\text { Rejected whole } \\
\text { and crushed }\end{array}$ \\
\hline Filefish & 484 & 90.5 & 7.6 & 1.9 \\
Spot & 262 & 72.9 & 16.8 & 10.3 \\
Pinfish & 294 & 86.7 & 10.2 & 3.1 \\
Coral & 181 & 87.7 & 5.5 & 1.7 \\
Total & 1221 & 85.2 & 10.9 & 4.0 \\
\hline
\end{tabular}


Fig. 1. Palatability of benthic invertebrate larvae to predators. The total number of larvae offered is shown by the number at the base of each bar; this number also represents the number of fish that were offered that type of larva. An asterisk or double asterisk indicates a significant difference $(p \leq$ 0.05 , or $p \leq 0.005$, respectively, Fisher's Exact test) between consumption of larval type and control foods by predators
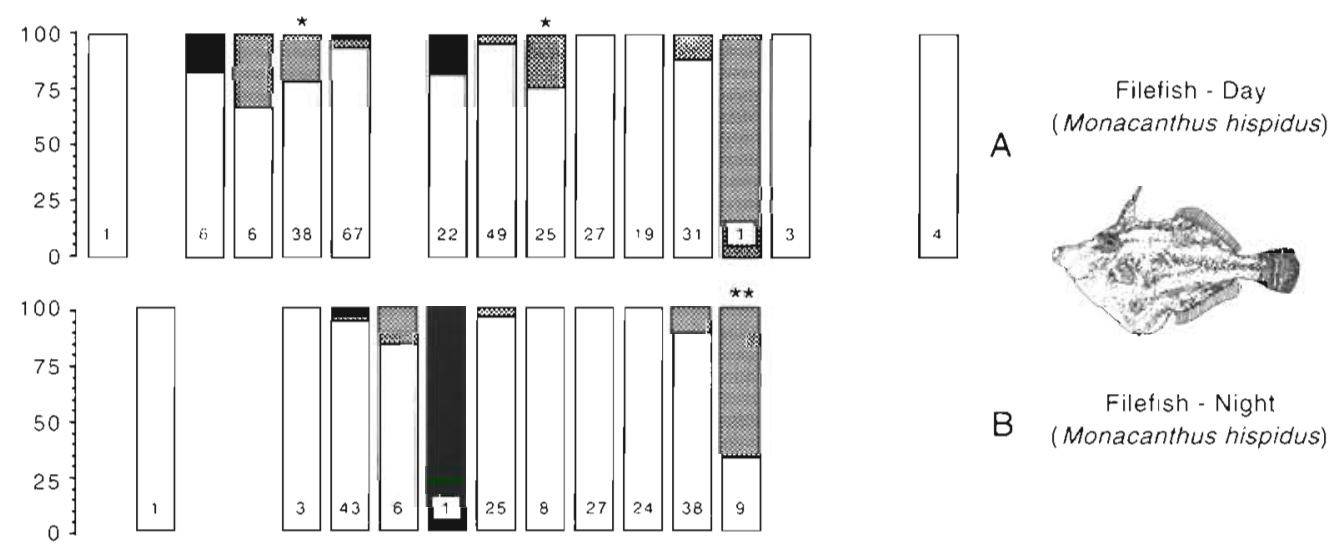

B Filefish - Night
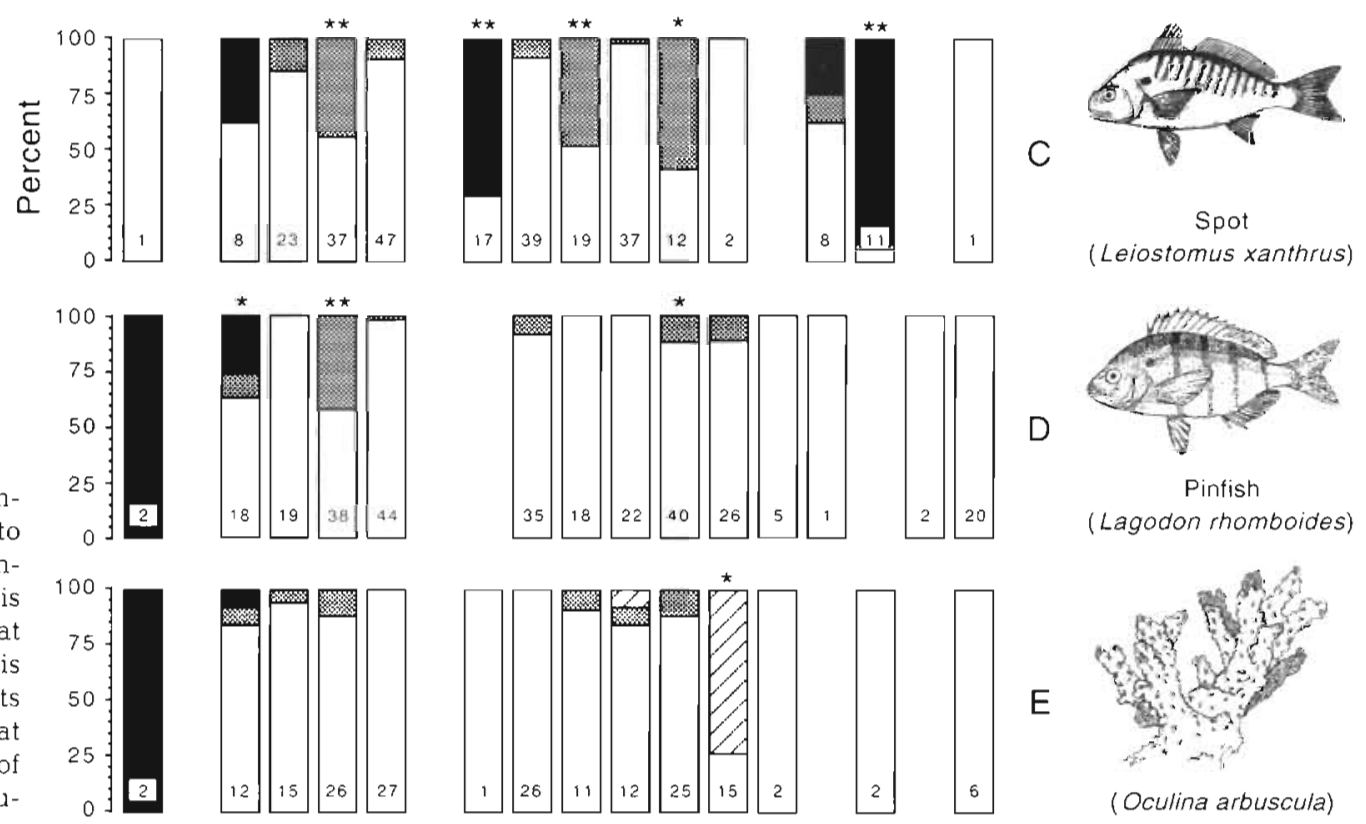

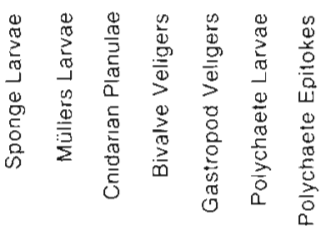

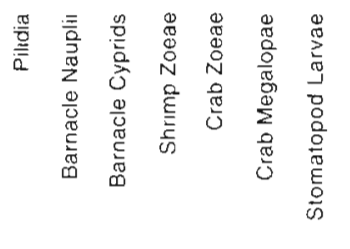

(Oculina arbuscula)

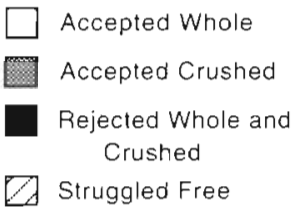

$44,53,42$, and $9 \%$, respectively, compared to $100 \%$ for brine shrimp) (Fig. 1C). Among these taxonomic groups, gastropod veligers, barnacle cyprids, and crab zoeae were accepted once they were crushed, suggesting a morphological defense. Pilidia and bipinnaria were rejected both whole and crushed, suggesting a chemical defense.

Pinfish consumed significantly fewer cnidarian planulae, gastropod veligers and crab zoeae than brine shrimp $(61,58$, and $87 \%$, respectively, compared to $100 \%$ for brine shrimp) (Fig. 1D). Gastropod veligers and crab zoeae were accepted once they were crushed, while planulae were generally rejected both whole and crushed. The biological relevance of the small $(13 \%)$, but statistically significant, proportion of crab zoeae rejected by pinfish can be debated; our large sample size for this assay $(n=40)$ provided more power than for most of our other assays. The results for crab zoeae would be relevant if the rejected larvae were of a single species; however, our data did not allow us to evaluate this possibility.

For corals, only crab megalopae were consumed less than brine shrimp controls ( $27 \%$ compared to $100 \%$ ) (Fig. 1E). Megalopae, however, were not rejected by the corals, but rather struggled free from polyps before they could be consumed. 
Table 2. Mean abundance of meroplankton groups. Values represent the mean abundance of meroplankton groups for each month of 1996 (day and night data pooled, $R A=$ relative abundance)

\begin{tabular}{|c|c|c|c|c|c|c|c|c|c|c|c|c|c|c|}
\hline \multirow{2}{*}{$\begin{array}{l}\text { Meroplankton } \\
\text { group }\end{array}$} & \multicolumn{12}{|c|}{ Abundance (no. $\mathrm{m}^{-3}$ ) } & \multicolumn{2}{|c|}{ Total abundance } \\
\hline & Dec & Jan & Feb & Mar & Apr & May & Jun & Jul & Aug & Sep & Oct & Nov & Mean & RA \\
\hline Sponge larvae & 0.00 & 0.00 & 0.00 & 0.00 & 0.00 & 0.00 & 0.00 & 0.00 & 0.00 & 0.00 & 0.00 & 0.00 & 0.00 & 0.000 \\
\hline Mülier's larvae & 0.00 & 0.00 & 0.00 & 0.00 & 0.00 & 0.00 & 0.00 & 0.00 & 0.00 & 0.00 & 0.00 & 0.00 & 0.00 & 0.000 \\
\hline Cnidarian planulae & 0.00 & 0.00 & 0.00 & 0.00 & 0.00 & 1.56 & 0.16 & 0.05 & 0.04 & 0.03 & 0.03 & 0.07 & 0.16 & $<0.001$ \\
\hline Bivalve veligers & 2.55 & 13.36 & 23.34 & 15.20 & 16.26 & 26.51 & 85.25 & 66.53 & 34.87 & 22.41 & 16.49 & 23.09 & 28.82 & 0.066 \\
\hline Gastropod veligers & 1.57 & 2.86 & 4.91 & 12.94 & 115.63 & 101.67 & 357.75 & 200.85 & 101.06 & 68.27 & 35.14 & 17.15 & 84.89 & 0.195 \\
\hline Polychaete larvae & 159.51 & 68.93 & 104.50 & 216.51 & 104.36 & 86.66 & 70.11 & 53.63 & 195.24 & 164.20 & 242.33 & 559.49 & 169.79 & 0.391 \\
\hline Nemertean pilidia & 0.79 & 0.92 & 0.75 & 0.27 & 0.07 & 1.05 & 0.30 & 1.49 & 0.20 & 0.05 & 0.36 & 0.97 & 0.60 & 0.001 \\
\hline Barnacle nauplii & 34.25 & 32.50 & 39.50 & 42.94 & 60.06 & 85.56 & 83.21 & 125.30 & 87.87 & 107.26 & 91.50 & 62.56 & 71.04 & 0.163 \\
\hline Barnacle cyprids & 2.03 & 1.70 & 5.01 & 8.33 & 11.79 & 48.93 & 106.60 & 221.87 & 24.97 & 11.93 & 11.47 & 7.83 & 41.04 & 0.094 \\
\hline Shrimp zoeae & 0.25 & 0.20 & 0.90 & 1.37 & 3.97 & 26.40 & 36.03 & 17.62 & 11.24 & 14.97 & 7.10 & 2.00 & 10.17 & 0.023 \\
\hline Crab zoeae & 0.05 & 0.00 & 0.04 & 0.00 & 0.45 & 63.13 & 101.32 & 39.17 & 30.84 & 22.99 & 2.31 & 0.89 & 21.77 & 0.050 \\
\hline Crab megalopae & 0.67 & 0.17 & 0.24 & 0.10 & 0.79 & 0.11 & 10.76 & 26.97 & 1.44 & 1.17 & 1.04 & 0.46 & 3.66 & 0.008 \\
\hline Stomatopod larvae & 0.00 & 0.00 & 0.00 & 0.00 & 0.00 & 0.00 & 0.00 & 0.00 & 0.00 & 0.00 & 0.00 & 0.00 & 0,00 & 0.000 \\
\hline Actinotrocha & 0.00 & 0.00 & 0.04 & 0.00 & 0.09 & 0.40 & 0.15 & 0.14 & 0.00 & 0.00 & 0.00 & 0.29 & 0.09 & $<0.001$ \\
\hline Asteroid bipınnaria & 0.46 & 2.99 & 0.55 & 0.94 & 0.61 & 0.33 & 0.11 & 0.18 & 0.00 & 0.00 & 0.00 & 0.00 & 0.51 & 0.001 \\
\hline Tadpole larvae & 0.00 & 0.06 & 0.00 & 0.00 & 0.69 & 10.97 & 3.20 & 2.61 & 0.41 & 0.10 & 0.03 & 0.07 & 1.51 & 0.003 \\
\hline Tornaria & 4.40 & 1.20 & 0.25 & 0.06 & 0.15 & 0.29 & 0.30 & 0.43 & 0.10 & 0.01 & 0.29 & 0.32 & 0.65 & 0.001 \\
\hline Total abundance & 206.53 & 124.89 & 180.03 & 298.66 & 314.92 & 453.57 & 855.25 & 756.84 & 488.28 & 413.39 & 408.09 & 675.19 & 434.70 & \\
\hline
\end{tabular}

\section{Temporal abundance of meroplankton}

Meroplankton abundance varied greatly between groups and months (Table 2). Ranked in descending order of total annual abundance, the most common members of the meroplankton community were: polychaete larvae, gastropod veligers, barnacle nauplii, barnacle cyprids, bivalve veligers, crab zoeae, shrimp zoeae, crab megalopae, tadpole larvae, hemichordate tornaria, nemertean pilidia, asteroid bipinnaria, cnidarian planulae, and phoronid actinotrocha.

\section{Diversity of larvae}

Our assays included 12 larval forms, at least 18 separate species, and 51 larval types (Table 3). Although individual species could be identified for only a subset of the larvae, characteristic larval types could be recognized for most taxonomic groups. The number of types identified within each taxonomic group varied from as low as 1 for Müller's larvae (flatworm larvae) and phoronid actinotrochs, to as high as 14 for polychaete larvae. In many cases, various sizes and stages of larvae

Table 3 . The diversity of larval forms found in samples taken concurrently with filefish assays (September and October 1996)

\begin{tabular}{|c|c|c|}
\hline Larval form & No. of 'types' & Species present \\
\hline Müller's larvae (flatworm) & 1 & \\
\hline Bivalve veligers & 4 & \\
\hline Gastropod veligers & 4 & \\
\hline Polychaete larvae & 14 & Chaetopterus sp.; Paedophylax dispar; Polydora sp.i Terebella sp. \\
\hline Pilidia (nemertean larvae) & 2 & \\
\hline Barnacle nauplii & 5 & $\begin{array}{l}\text { Balanus eburneus: stages } 4 \& 5 ; B \text {. improvisus: stages } 5 \& 6 ; B \text {. amphitrite: } \\
\text { stages } 2,3, \& 4 ; \text { Chthamalus fragilius: stage } 2 ; \text { Nauplius 'SC': stage } 2\end{array}$ \\
\hline Barnacle cyprids & 3 & \\
\hline Crab zoeae & 7 & $\begin{array}{l}\text { Euceramus praelongus: stage } 1_{i} \text { Hexapanopeus angustifrons: stages } 1 \& 4_{i} \\
\text { Menippe mercenaria: stage } 1_{i} \text { Pinnixa chaetopterana: stage } 1_{i} \text { Pinnixa } \\
\text { cylindrica: stage } 2_{i} \text { Sesarma cinereum: stages } 1 \& 4_{i} \text { Uca sp: stages } 1 \& 5\end{array}$ \\
\hline Crab megalopae & 4 & Callinectes sapidus; Hexapanopeus angustifrons; Sesarma cinereum; Uca sp. \\
\hline Stomatopod larvae & 1 & Squilla sp. \\
\hline Shrimp zoeae & 5 & \\
\hline Acinotrochs & 1 & \\
\hline
\end{tabular}


were present within individual larval species or types; for example, multiple stages were present within 3 species of barnacle nauplii and 3 species of crab zoeae.

\section{DISCUSSION}

For all larvae tested, $85 \%$ were readily eaten when whole. Within the taxonomic groups of larvae examined, polychaete larvae, barnacle nauplii, bivalve veligers, shrimp zoeae, crab megalopae, phoronid actinotrocha, and hemichordate tornaria (which together accounted for $65 \%$ of meroplankton abundance) lacked morphological or chemical defenses that deterred feeding under our laboratory conditions. Larvae of the remaining taxonomic groups were consumed at significantly lower rates than the control food by at least 1 species of predator. Thus, a significant number of individuals from an undetermined number of species within these taxonomic groups had traits that deterred some consumers.

Within taxonomic groups showing some resistance to consumers, morphology seemed to deter feeding more commonly than chemistry. Gastropod veligers, barnacle cyprids, crab zoeae, and stomatopod larvae (which accounted for $34 \%$ of overall meroplankton abundance), were often rejected while physically intact but were readily consumed when crushed, suggesting a morphological defense. Among nemertean pilidia, asteroid bipinnaria, and cnidarian planulae (which accounted for only $0.2 \%$ of overall meroplankton abundance), more than $90 \%$ of larvae that were rejected whole were also rejected when crushed, suggesting that distasteful larvae in these groups are chemically unpalatable.

Our study used only field-captured larvae for palatability assays. Collecting larvae from the field has both advantages and disadvantages over culturing larvae in the laboratory. First, because many types of larvae, such as nemertean pilidia and stomatopod larvae, are difficult to obtain through laboratory culturing methods (Strathmann 1987), field collection allows for a wider variety of larval types to be offered to predators. Second, larvae that have been collected from the field are representative of the 'natural' larval condition. Field-captured larvae have been exposed to their normal prey items, have been able to feed at natural rates and have already been exposed to some types of selection. Induced defenses or dietary derived defenses that might be present in natural populations may be absent from laboratory-reared larvae.

Counter-balancing the benefits of using field-captured larvae is the difficulty of adequately identifying them. Although it is easy to classify field-captured larvae to taxonomic groups (e.g. polychaete larvae, bar- nacle nauplii, etc.), it is very difficult, often impossible, to identify live, field-captured larvae to the species level. Therefore, we are uncertain how many different species of larvae were offered to predators during our assays. As it was our intention to determine the palatability of the greatest taxonomic diversity of larvae, sampling protocols were employed that helped maximize the number of larval forms obtained. In many cases, unique larval types were observed in the living plankton samples that were not subsequently seen in preserved archive samples. It is therefore likely that the number of species recorded from the archive samples (Table 3) for each larval group underestimated the number of larval types that were presented to predators. It should also be noted that in addition to specieslevel diversity there were often several different developmental stages collected for some species. For example, multiple larval stages were present within 3 of 5 species of barnacle nauplii and 3 of 7 crab zoeae species identified.

Our methods tested for morphological and chemical defenses of larvae. Although behavioral evasion of predators may be common in larvae of some taxa (Forward 1976, 1977. Young 1995), our assays tested only the outcome of a larva-predator encounter once the larva entered the predator's mouth. Larvae in our study were attacked by predators as soon as they were released from the tip of the pipette. Thus, we did not allow larvae to behaviorally evade predators. Additionally, some species of larvae may gain a spatio-temporal refuge from predators by avoiding portions of the water column where visual predators are active, or by being released at a time of year when predators are absent (Shanks 1986, DeVries et al. 1994). Our temporal abundance data, however, suggest that larvae at this temperate location are most abundant from spring to fall, the time period when potential larval predators are most abundant (Hay \& Sutherland 1988). Although our methodologies do not allow us to specifically assess the behavioral responses of larvae to predators, it is likely that some behavioral responses that may play a defensive function, such as spine flaring (Pennington \& Chia 1984, Morgan 1987, 1995), were exhibited by some larvae in our study.

Species of some taxonomic groups such as sponges, benthic cnidarians, sea stars, bryozoans, and colonial ascidians are known to possess chemically unpalatable larvae (Lucas et al. 1979, Young \& Bingham 1987. Lindquist et al. 1992, Lindquist \& Hay 1996, McClintock \& Baker 1997). Larvae of these groups, however, were exceedingly rare in our plankton samples, and thus poorly represented in our palatability assays. Although larvae of these groups were rare in the plankton, adults of these groups are often the dominant members of fouling communities on North Car- 
olina hard-bottoms (Sutherland 1981, Hay \& Sutherland 1988), and were abundant at the site where our plankton samples were taken. Since these organisms typically produce large, conspicuous larvae (Lindquist \& Hay 1996), it is unlikely that we failed to notice them in our samples. It is more plausible that these larvae were absent from the water column when we sampled. Very low numbers of these larvae were collected during our intensive year-long sampling program; we therefore hypothesize that the larvae of sponges, benthic cnidarians, bryozoans, and colonial ascidians were not abundant in the water column because they settled or were consumed shortly after their release (Olson \& McPherson 1987, Davis \& Butler 1989, Stoner 1990).

Previous work has suggested that chemical defenses in larvae may be linked to life-history mode (Lindquist 1996, Lindquist \& Hay 1996). Organisms that brood large lecithotrophic larvae have been suggested to have a greater tendency to produce chemically defended larvae than broadcast spawners that produce planktotrophic larvae (Lindquist \& Hay 1996). Few lecithotrophic larvae were available for our assays and so we cannot rigorously assess this hypothesis. However, 2 of the 3 taxonomic groups of larvae that appeared to have chemical defenses in this study were long-lived planktotrophs (nemertean pilidia and starfish bipinnaria). Chemical defenses in larvae, therefore, may be limited to certain taxonomic groups that are known to produce bioactive secondary metabolites in the adult stage, rather than being tied to specific reproductive traits.

\section{CONCLUSIONS}

The vast majority of field-captured larvae were readily consumed by predators. For those individuals or species that were rejected by consumers, morphological defenses appear to be more common than chemical defenses. However, larval defenses in general seem to be uncommon among temperate meroplankton. These findings suggest that the broadly assumed, but largely untested, notion that most planktotrophic larvae are palatable (and thus are very susceptible to co-occurring predators) is justified - at least for the system we investigated.

Acknowledgements. Funding for this project was provided by NSF grant OCE 95-29784 and a National Undersea Research Center grant (NURC/UNCW 94-11) to M.E.H., and by an NSF pre-doctoral fellowship to S.G.B. We thank E. Cruz-Rivera, J Stachowicz, P. Wojcik, and L. Hill for assistance with collection and maintenance of fish and plankton, and the captain and crew of the RV 'Elusive'. In addition, comments by $E$. Sotka, M. Dozier, L. Manning, and 3 anonymous reviewers greatly improved the manuscript.

\section{LITERATURE CITED}

Baier CT, Purcell JE (1997) Trophic interactions of chaetognaths larval fish, and zooplankton in the South Atlantic Bight. Mar Ecol Prog Ser 146:43-53

Bingham BL, Walters LJ (1989) Solitary ascidians as predators of invertebrate larvae: evidence from gut analyses and plankton samples. J Exp Mar Biol Ecol 131:147-159

Burrell VG, Van Engel WA (1976) Predation by and distribution of a ctenophore, Mnemiopsis leidyi A. Agassiz, in the York River Estuary. Estuar Coast Mar Sci 4:235-242

Clements WH, Livingston RJ (1983) Overlap and pollutioninduced variability in the feeding habits of filefish (Pisces: Monacanthidae) from Apalachee Bay, Florida. Copeia 2: $331-338$

Davis AR, Butler AJ (1989) Direct observations of larval dispersal in the colonial ascidian Podoclavella moluccensis Sluiter: evidence for close populations. J Exp Mar Biol Ecol 27:189-203

DeVries MC, Tankersley RA, Forward RB Jr, Kirby-Smith WW, Luettich RA Jr (1994) Abundance of estuarine crab larvae is associated with tidal hydrologic variables. Mar Biol 118:403-413

Feigenbaum DL, Maris RC (1984) Feeding in the chaetognatha. Oceanogr Mar Biol Ann Rev 22:343-392

Forward RB (1976) A shadow response in a larval crustacean. Biol Bull 151:126-140

Forward RB (1977) Occurrence of a shadow response among Brachyuran larvae. Mar Biol 39:331-341

Gerking SD (1994) Feeding ecology of fish. Academic Press Inc, San Diego

Glynn PW (1973) Ecology of a Caribbean coral reef. The Porites reef-flat biotope: Part II. Plankton cornmunity with evidence for depletion. Mar Biol 22:1-21

Hay ME, Sutherland JP (1988) The ecology of rubble structures of the South Atlantic Bight: a community profile. Biol Rep 85(7.20)

Hettler WF Jr, Peters DS, Colby DR, Laban EH (1997) Daily variability in abundance of larval fishes inside Beaufort Inlet. Fish Bull 95:477-493

Hobson ES, Chess JR (1976) Trophic interactions among fishes and zooplankters near shore at Santa Catalina Island, California. Fish Bull 74:567-598

Kjelson MA, Peters DS, Thayer GW, Johnson GN (1975) The general feeding ecology of postlarval fishes in the Newport River estuary. Fish Bull 73:137-144

Lindquist $N$ (1996) Palatability of invertebrate larvae to corals and anemones. Mar Biol 126:745-755

Lindquist $N_{\text {, Hay }}$ ME (1995) Can small rare prey be chemically defended? The case for marine larvae. Ecology 76 : $1347-1358$

Lindquist N, Hây ME (1996) Palatability and chemical defense of marine invertebrate larvae. Ecol Monogr 66: $431-450$

Lindquist N, Hay ME, Fenical W (1992) Defense of ascidians and their conspicuous larvae; adults vs. larval chemical defenses. Ecol Monogr 62:547-568

Lindquist $N$, Bolser $R$, Laing $K$ (1997) Timing of larval release by two Caribbean demosponges. Mar Ecol Prog Ser 155 309-313

Lucas JS, Hart RJ, Howden ME, Salathe R (1979) Saponins in the eggs and larvae of Acanthaster planci (L.) (Asteroidea) as chemical defenses against planktivorous fish. J Exp Mar Biol Ecol 40:155-165

McClintock JB, Baker BJ (1997) Palatability and chemical defense of eggs, embryos and larvae of shallow-water Antarctic marine invertebrates. Mar Ecol Prog Ser 154:121-131 
McClintock JB, Vernon JD (1990) Chemical defense in the eggs and embryos of Antarctic sea stars (Echinodermata). Mar Biol 105:491-495

Miller MW, Hay ME (1996) Coral-seaweed-grazer-nutrient interactions on temperate reefs. Ecol Monogr 66:323-344

Morgan SG (1987) Morphological and behavioral antipredatory adaptations of decapod zoeae. Oecologia 73:393-400

Morgan SG (1989) Adaptive significance of spination in estuarine crab zoeae. Ecology 70:464-482

Morgan SG (1995) Life and death in the plankton: larval mortality and adaptation. In: McEdward LR (ed) Ecology of marine invertebrate larvae. CRC Press, Boca Raton, FL, p 279-321

Morgan SG, Christy JH (1996) Survival of marine larvae under the countervailing selective pressures of photodamage and predation. Limnol Oceanogr 41:498-504

Olson RR, McPherson R (1987) Potential vs, realized dispersal: fish predation on the larvae of the ascidian Lissoclinum patella (Gottschaldt). J Exp Mar Biol Ecol 110:245-256

Pennington JT, Chia FS (1984) Morphological and behavioral defenses of trochophore larvae of Sabellaria cementarium (Polychaeta) against four planktonic predators. Bio Bull 167:168-175

Purcell JE, Nemazie DA (1992) Quantitative feeding ecology of the hydromedusan Nemopsis bachei in Chesapeake Bay. Mar Biol 113:305-311

Reeve MR, Walter MA (1978) Nutritional ecology of ctenophores - a review of recent research. Adv Mar Biol 15:249-287

Rumrill SS (1990) Natural mortality of marine invertebrate larvae. Ophelia 32:163-198

Sebens KP, Koehl MAR (1984) Predation on zooplankton by the benthic anthozoans Alcyonium siderium (Alcyonacea) and Metridium senile (Actinaria) in the New England subtidal. Mar Biol 81:255-271

Shanks AL (1986) Vertical migration and cross-shelf dispersal of larval Cancer spp. and Randallia ornata (Crustacea:

Editorial responsibility: Otto Kinne (Editor),

Oldendorf/Luhe, Germany
Erachyura) off the coast of southern California. Mar Biol 92:189-199

Staciowicz JJ, Lindquist N (1996) Chemical defense among hydroids on pelagic Sargassum: predator deterrence and absorption of solar UV radiation by secondary metabolites. Mar Ecol Prog Ser 155:115-126

Stoner DS (1990) Recruitment of a tropical colonial ascidian: relative importance of pre-settlement vs. post-settlement processes. Ecology 71:1682-1690

Strathmann MF (1987) Reproduction and development of marine invertebrates of the northern Pacific coast. Univers.ty of Washington Press. Seattle

Sutherland JP (1981) The fouling community at Beaufort. North Carolina: a study in stability. Am Nat 118:499-519

Thayer GW, Hoss DE, Kjelson MA, Hettler WF Jr, Lacroix MW (1974) Biomass of zooplankton in the Newport River estuary and the influence of post larval fishes. Chesapeake Sci $15: 9-16$

Thorson G (1946) Reproduction and larval development of Danish marine bottom invertebrates. Medd Dan Fisk Havunder Serie: Plankton 4:1-523

Weinstein MP (1979) Shallow marsh habitat as primary nurseries for fishes and shellfish, Cape Fear River, North Carolina. Fish Bull 77:339-357

Young CM (1995) Behavior and locomotion during the dispersal phase of larval life. In: McEdward LR (ed) Ecology of marine invertebrate larvae. CRC Press, Boca Raton, FL, p 249-277

Young CM, Bingham BL (1987) Chemical defense and aposematic coloration in larvae of the ascidian Ecteinascidia turbinata. Mar Biol 96:539-544

Young CM, Chia FS (1987) Abundance and distribution of pelagic larvae as influenced by predation, behavior, and hydrographic factors. In: Giese C, Pearse JS, Pearse VB (eds) Reproduction of marine invertebrates, Vol 9. Blackwell Scientific, Palo Alto, and The Boxwood Press, Pacific Grove, CA, p 385-463

Submitted: February 2, 1999; Accepted: May 20, 1999 Proofs received from author(s): December 20, 1999 